Arq. Bras. Med. Vet. Zootec., v.59, n.1, p.85-89, 2007

\title{
Cardiac trauma confirmed by cardiac markers in dogs: two case reports
}

\author{
[Trauma cardíaco confirmado por marcadores cardíacos em cães: relato de dois casos] \\ P.P.V.P. Diniz ${ }^{1}$, D.S. Schwartz ${ }^{2 *}$, R.C. Collicchio-Zuanaze ${ }^{1}$ \\ ${ }^{1}$ Aluno de pós-graduação - FMVZ-UNESP - Botucatu, SP \\ ${ }^{2}$ Faculdade de Medicina Veterinária e Zootecnia-UNESP - Botucatu, SP
}

\begin{abstract}
Two clinical cases of cardiac contusion in dogs were studied Radiographic evaluation showed pneumothorax and alveolar pattern on diaphragmatic pulmonary lobe in one dog, and arrhythmias in both dogs. Cardiac troponin I and CK-MB serum analysis associated with clinical history and eletrocardiographic findings indicated accurately the extension of myocardial injury secondary to trauma. Keywords: dog, troponin I, CK-MB, arrhythmia, myocardial injury
\end{abstract}

\section{RESUMO}

Relatam-se dois casos de miocardite em cães. A avaliação radiográfica mostrou pneumotórax e padrão alveolar no lobo diafragmático pulmonar em um cão e arritmia em ambos os cães. As análises das proteinas cardiacas altamente sensíveis, como a CK-MB e a troponina I cardiaca, associadas ao histórico clínico e aos achados eletrocardiográficos, indicaram, com acurácia, a extensão da injúria miocárdica secundária ao trauma.

Palavras-chave: cão, CK-MB, troponina I, arritmia, miocardite traumática

\section{INTRODUCTION}

Blunt thoracic trauma resulting from vehicle collision, falls, kicks, or from cardiac resuscitative procedures may cause direct damage to the heart of animals as it does in humans (Abbott, 1995; Swaanenburg et al., 1998; Schober et al., 2001). Cardiac injury is not necessarily followed by fractures of the bony structures of the chest wall (Schober et al., 2001), but includes histopathological findings such as multifocal areas of hemorrhage and acute degeneration or necrosis of muscle fibers (Wynne and Braunwald, 1997; Schober et al., 1999). The potentially serious consequences of myocardial injury are life-threatening arrhythmias or acute cardiac failure (Macintire and Snider, 1984; Abbott, 1995).

Recebido em 8 de junho de 2005

Aceito em 4 de dezembro de 2006

*Endereço para correspondência (corresponding address)

VCM-FMVZ-USP - Av. Prof. Dr. Orlando Marques de Paiva, 87

05508-270 - São Paulo, SP

E-mail: dschwartz@usp.br

Apoio: FAPESP - projetos: 02/11117-1, 03/02627-9, 04/09313-2
Diagnosing myocardial damage as a result of trauma may be difficult due to the lack of a "gold standard" method of diagnosis (Swaanenburg et al., 1998). Electrocardiographic (ECG) alterations (Q-wave, and ST-T abnormalities, arrhythmias) and echocardiographically detectable regional wall motion abnormalities have been considered in clinical investigation, however, their diagnostic sensitivity to confirm minor myocardial injury are rather low (Schober et al., 2001).

In recent years, the analysis of circulating highly specific cardiac proteins has increased the accuracy of heart trauma diagnosis. The parameters of higher specificity for myocardial cell injury in people are the MB isoenzyme of 
CK (CK-MB) and cardiac troponin I (cTnI) (Schober et al., 1999). CK-MB has been the standard biochemical marker for detection of acute myocardial infarction in humans, however, tissue specificity has been shown not to be absolute (Apple, 1999). Cardiac troponin I, a subunit of the troponin complex that regulates the calcium-modulated interaction of actin and myosin in cardiac muscle, has been recognized as the most sensitive and specific marker of myocardial necrosis in humans (Adams et al., 1993; Sleeper et al., 2001). Troponin I is also found in skeletal muscle, however, the cardiac form is produced by a specific gene, with unique amino acid sequence. Thus, monoclonal antibodies to cTnI have no cross-reactivity with the skeletal muscle forms (Adams et al., 1993). The experimental use of human serologic tests for cTnI analysis in dogs and cats has provided good results because these proteins are highly phylogenetically preserved, with more than $95 \%$ total structural agreement and genetic homology between these species (O'Brien et al., 1997; Schober et al., 2001). The assays developed for humans have been validated in many species (Herndon et al., 2002; Oyama and Sisson, 2003).

The aim of this study is to report two clinical cases of cardiac trauma in dogs, which have been diagnosed and followed by CK-MB and cTnI serological analysis, and to discuss the clinical viability of these methods in Veterinary practice in Brazil.

\section{CASE REPORT}

Two dogs with history of being hit by a car with two days of evolution were referred to the Veterinary Teaching Hospital of São Paulo State University - Botucatu. Dog $n^{0} 1$ was a four year old male Belgium Shepherd and $\operatorname{dog} \mathrm{n}^{\circ} 2$ was an eight-year-old mixed breed male. On initial clinical exam, both were depressed, anorectic and had hind limb fractures, but external lesions on the chest wall were not observed. The radiographic evaluation showed pneumothorax and alveolar pattern on diaphragmatic pulmonary lobe only in $\operatorname{dog} n^{\circ} 1$. However, arrhythmia was diagnosed electrocardiographically in both dogs (Fig. 1A and Fig. 2A) with paroxysmal and sustained ventricular tachycardia. $\mathrm{CK}-\mathrm{MB}^{1}$ and

${ }^{1}$ CK-MB Liquiform - Labtest Diagnóstica Ltda., Lagoa Santa, MG
$\mathrm{cTnI}^{2}$ were measured in serum and myocardial injury was confirmed by the high levels of cardiac markers obtained (Fig. 3).

Opioid analgesics and support therapy were introduced. Antiarrhythmic therapy was based on lidocaine infusion $(50-75 \mu \mathrm{g} / \mathrm{kg} / \mathrm{min}$ during 3-8 hours) and $\beta$-adrenergic blocker (propranolol $0.2-0.4 \mathrm{mg} / \mathrm{kg}$ PO TID 7-10 days), and both dogs showed electrocardiographic abnormalities resolution between 4 and 9 days (Fig. 1B and Fig. 2B). The serum level of cardiac markers during and post-therapy were monitored by two consecutive analyses, and showed progressive decrease (Fig. 3). Almost one year after the trauma, according to the owner contacted by telephone, $\operatorname{dog} \mathrm{n}^{\circ} 1$ has been asymptomatic. Dog $\mathrm{n}^{\mathrm{o}} 2$ died weeks after leaving the hospital.

\section{DISCUSSION}

According to international literature, the use of cardiac markers in Veterinary Cardiology have been widespread due to the decrease of assays' cost and the importance of early diagnosis of cardiac damage from a therapeutic and prognostic perspective (Schober et al., 2001; Sleeper et al., 2001; Herndon et al., 2002). In Brazil, these markers have been used essentially for research purposes; therefore, this report describes the first application of this technology for clinical diagnosis.

In normal dogs, CK-MB reference range is 4.9$6.3 \mathrm{UI} / 1$ according to Montes et al. (1987). In the present reported cases, after two days of trauma, the serum activity of CK-MB was $3882\left(\operatorname{dog} n^{\circ} .1\right)$ and 8030UI/1 (dog $\mathrm{n}^{\circ}$ 2) (Fig. 3), suggesting an extensive myocardial injury. However, the tissue specificity of CK-MB has been shown not to be absolute due to its presence in skeletal muscle besides myocardial muscle, both types being released into blood stream following trauma (Swaanenburg et al., 1998; Apple, 1999). Therefore, skeletal muscle injury characterized by hind limb fractures could have affected CK-MB concentration in theses cases, mainly for $\operatorname{dog} n^{\circ} 2$, who had fractures in both legs.

\footnotetext{
${ }^{2}$ Cardiac Troponin I Flex- Dimension RxL - Dade Behring Inc., EUA
} 


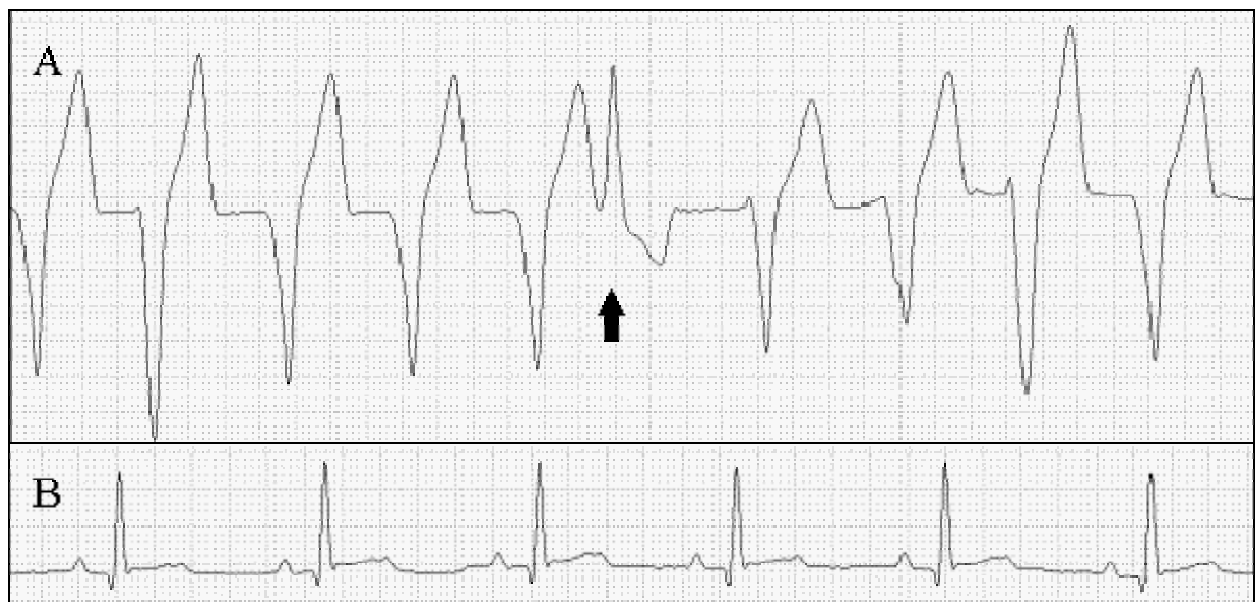

Figure 1. ECG record of $\operatorname{dog} \mathrm{n}^{\circ} 1$ on day two (A) and day four (B) after blunt thoracic trauma. On "A": sustained ventricular tachycardia with R-on-T phenomenon (arrow). On "B": sinus rhythm following anti-arrhythmic therapy. Lead DII, $50 \mathrm{~mm} / \mathrm{s}$.

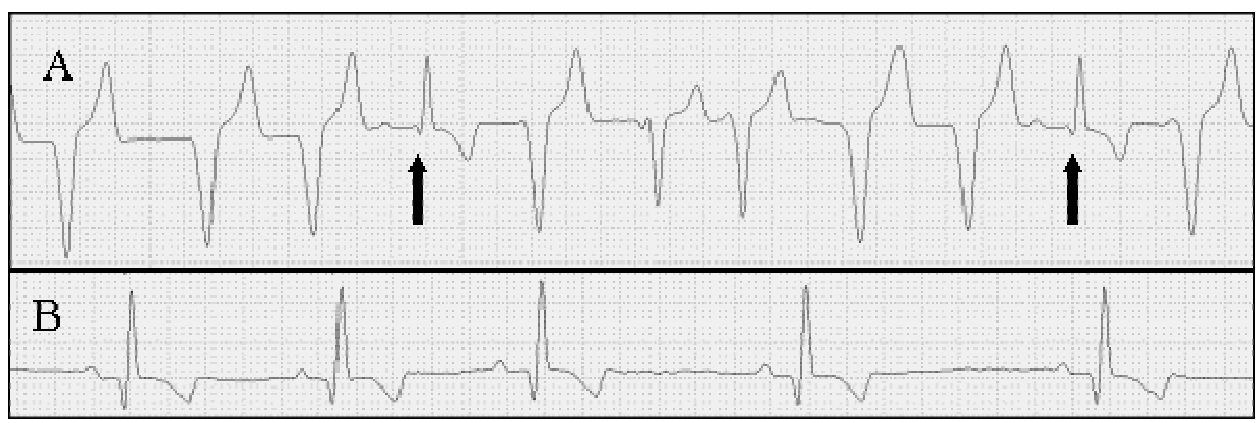

Figure 2. ECG record of $\operatorname{dog} \mathrm{n}^{\circ} 2$ on day two (A) and day nine (B) after blunt thoracic trauma. On "A": ventricular tachycardia with sinus capture beats (arrows). On "B", sinus rhythm with complete resolution of arrhythmias. Lead DII, $50 \mathrm{~mm} / \mathrm{s}$
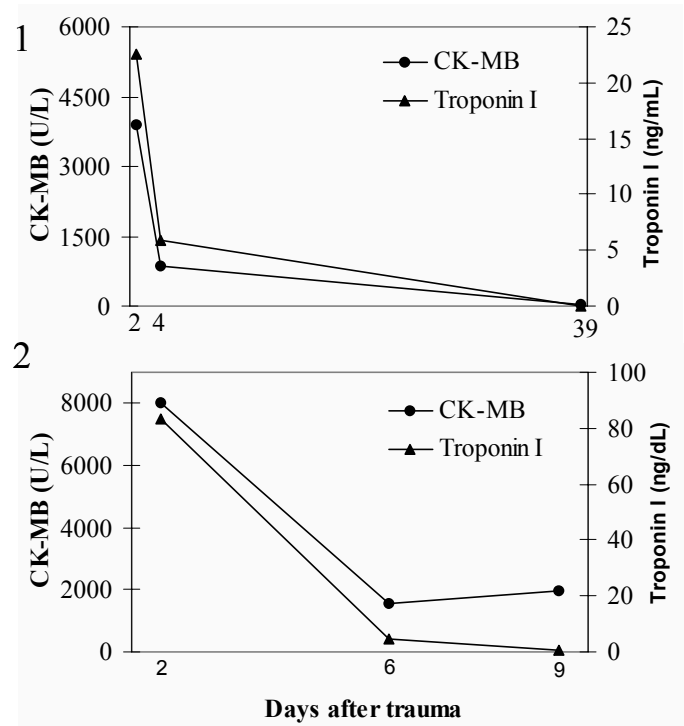

Figure 3. Progression of serum levels of CK-MB and cardiac troponin I from dogs $n^{\circ} 1$ and $n^{\circ} 2$. Reference range for $\mathrm{CK}-\mathrm{MB}=4.9-6.3 \mathrm{UI} / \mathrm{l}$ and for cardiac troponin $\mathrm{I}<0.03-0.07 \mathrm{ng} / \mathrm{ml}$. Attention to differences in days after trauma and concentration scales. 
In dogs, intestines, spleen and lungs have a particular importance in CK-MB concentration, because these organs have high isoenzyme activity and when associated, represent $85 \%$ of total CK-MB activity (Aktas et al., 1993). Hence, in $\operatorname{dog} \mathrm{n}^{\mathrm{o}} 1$, a partial component of the high CKMB activity could be due to lung trauma, as shown by radiographic evaluation.

The consecutive measurements of CK-MB serum activity during therapy showed the typical decrease described in humans and dogs (Aktas et al., 1993; Bhayana and Henderson, 1995), except for the third CK-MB determination in $\operatorname{dog} \mathrm{n}^{\mathrm{o}} 2$ (Fig. 3), which could be related to surgical procedures performed to correct hind limb fractures and prolonged recumbency.

Cardiac troponin I has been recognized as the most sensitive and specific marker for myocardial cell damage in humans (Apple et al., 1998) and animals (Schober et al., 2001). The diagnostic time window of this marker in humans is wide, being up to 72 hours (Lobetti et al., 2002). The cTnI range for normal dogs is $<0.03-0.07 \mathrm{ng} / \mathrm{ml}$ (Sleeper et al., 2001). In the reported cases, the first cTnI determinations showed high serum levels of 22 and 83ng/dl (Fig. 3), strongly suggestive of myocardial injury. Increases in cTnI have been described in humans and animals in many cardiac diseases and also in noncardiac disorders as sepsis, pulmonary embolism, neoplasms and inflammatory processes, but these elevations were always related to cardiac muscle damage (Schober et al., 2001; Lobetti et al., 2002). The serum level of cTnI are proportional to the severity of myocardial damage (Apple et al., 1998; Oyama and Sisson, 2003), thus the results strongly suggest that the dogs described here had a massive heart injury.

After four and six days of chest trauma, serum cTnI level were still high in both patients $\left(\operatorname{dog} \mathrm{n}^{\circ}\right.$ $1=5.88 \mathrm{ng} / \mathrm{dl} ; \operatorname{dog} \mathrm{n}^{\circ} 2=4.85 \mathrm{ng} / \mathrm{dl}$ ) (Fig. 3), denoting a continuous release of myocardial proteins from damage tissues because the circulating half-life of cTnI is approximately two hours (Schober, 2001).

Adams et al. (1993) observed no elevations of cTnI in human patients with acute or chronic muscle disease or renal failure except when evidence of cardiac injury was present. Thus, these authors proposed cTnI as a confirmative analysis while elevations of CK-MB may be indicative of myocardial injury or may be a consequence of skeletal muscle and/or noncardiac organ injury.

Electrocardiographic evaluations of the dogs following the traumatic myocarditis patterns have been described by many authors (Abbott, 1995; Schober et al., 1999). Many aspects are involved on the genesis of these arrhythmias, as abnormal automaticity, cytokines, disturbance of autonomic balance, ischemia and reperfusion of ischemic tissues. In theses cases, antiarrhythmic therapy is essential to prevent the risk of lethal arrhythmias, such as ventricular fibrillation, or adverse hemodynamic effects (Abbot, 1995).

Cardiac troponin I and CK-MB serum analyses associated with clinical history and electrocardiographic findings indicated accurately the extension of myocardial injury secondary to trauma in these reported cases.

It is concluded that cardiac markers are exceptional diagnostic tools in Veterinary Medicine since they are easily performed, sensitive and specific indicators of cardiac damage in dogs with blunt chest trauma. Moreover, CK-MB and cTnI have wide utilization potential in many other cardiac and non-cardiac diseases to diagnose myocardial abnormalities in dogs and cats.

\section{ACKNOWLEDGEMENTS}

We are grateful to the Hospital Santa Helena in São Paulo for the eTnI measurements, the Laboratório de Análises Clínicas da Faculdade de Medicina in Botucatu for CK-MB analysis and the staff of the FMVZ - UNESP who contributed to the case selection and sample collection.

\section{REFERENCES}

ABBOTT, J.A. Traumatic Myocarditis. In: BONAGURA, J.D. (Ed). Kirk's current veterinary therapy. v.XII. Philadelphia: W.B. Saunders, 1995. p.846-850.

ADAMS, J.E.; BODOR, G.S.; DÁVILAROMÁN, V.G. et al. Cardiac troponin I: a marker 
with high specificity for cardiac injury. Circulation, v.88, p.101-106, 1993.

AKTAS, M.; AUGUSTE, D.; LEFEBVRE, H.P. et al. Creatine kinase in the dog: a review. Vet. Res. Comm., v.17, p.353-369, 1993.

APPLE, F.S. Tissue specificity of cardiac troponin I, cardiac troponin $\mathrm{T}$ and creatine kinase-MB. Clin. Chim. Acta, v.284, p.151-159, 1999.

APPLE, F.S.; SHARKEY, S.W.; FALAHATI, A. et al. Assessment of left ventricular function using serum cardiac troponin I measurements following myocardial infarction. Clin. Chim. Acta, v.272, p.59-67, 1998.

BHAYANA, V.; HERDENSON, A.R. Biochemical markers of myocardial damage. Clin. Biochem, v.28, p.1-29, 1995.

HERNDON, W.E.; KITTLESON, M.D.; SANDERSON, K. et al. Cardiac troponins I in feline hypertrophic cardiomyopathy. J. Vet. Intern. Med., v.16, p.558-564, 2002.

LOBETTI, R.; DVIR, E.; PEARSON, J. Cardiac troponins in canine babesiosis. J. Vet. Intern. Med., v.16, p.63-68, 2002.

MACINTIRE, D.K.; SNIDER, T.G. Cardiac arrthythmias associated with multiple trauma in dogs. J. Am. Vet. Med. Assoc., v.184, p.541-545, 1984.

MONTES, A.M.; GUTIÉRREZ-PANIZO, C.; GARCÍA-PARTIDA, P. et al. CK-MB, LDG and ASAT in dogs of different ages with infarct of miocardium. An. Vet. (Murcia), v.2, p.101-108, 1987.

O'BRIEN, P.; LANDT, Y.; LADENSON, J.H. Differential reactivity of cardiac and skeletal muscle from various species in a cardiac troponin
I immunoassay. Clin. Chem., v.43, p.2333-2338, 1997.

OYAMA, M.A.; SISSON, D.D. Blood-based detection of occult heart disease. In: ANNUAL VETERINARY MEDICAL FORUM, 21., 2001, Charlotte. Proceedings... Charlotte: American College of Veterinary Internal Medicine, 2003. p.88-89.

SCHOBER, K.E.; KIRBACH, B.; OECHTERING, G. Noninvasive assessment of myocardial cell injury in dogs with suspected cardiac contusion. J. Vet. Cardiol., v.1, p.17-25, 1999.

SCHOBER, B.K.; KIRBACH, B.; CORNAND, C. et al. Circulating cardiac troponins in small animal. In: ANNUAL VETERINARY MEDICAL FORUM, 19, 2001, Denver. Proceedings... Denver: American College of Veterinary Internal Medicine, 2001. p.91-92.

SLEEPER, M.M.; CLIFFORD, C.A.; LASTER, L.L. Cardiac troponin I in the normal dog and cat. J. Vet. Intern. Med., v.15, p.501-503, 2001.

SWAANENBURG, J.C.J.M.; KLAASE， J.M.; DEJONGSTE, M.J.L. et al. Troponin I, troponin $\mathrm{T}$, CKMB - activity and CKMB - mass as markers for the detection of myocardial contusion in patients who experienced blunt trauma. Clin. Chim. Acta, v.272, p.171-181, 1998.

WYNNE, J.; BRAUNWALD, E. Miocardiopatias e miocardites. In: BRAUNWALD, E. (Ed.). Tratado de medicina cardiovascular. 5.ed. São Paulo: Roca, 1999. v.2, p.1503-1566. 